\title{
Integrating disability and developmental theories for an equitable inclusive education: towards transformative educational praxes ${ }^{1}$
}

Dušana Podlucká2

\begin{abstract}
The US higher education institutions are legally bound to provide equal educational opportunities for diverse learners. This paper contends that despite the growing interest in implementing more inclusive pedagogy, those efforts still fall short of systematically addressing intersecting, oppressive, and anti-ableist practices in the classroom. I call for a theory that frames disability in the context of learning and development and overcomes dichotomized, reductionist and individualistic notions of disability and learning. Drawing on Critical Disability Studies, Vygotsky's theory of defectology and the Transformative Activist Stance, this paper outlines a transformative pedagogy framework for inclusive, equitable, and anti-ableist education for all learners.
\end{abstract}

Key Words: Disability, Anti-ableist transformative pedagogy, Transformative Activist Stance.

Integrando teorias de deficiência e do desenvolvimento para produzir práticas educativas justas e inclusivas: em busca de praxes educacionais transformativas

Resumo

Instituições de ensino superior nos Estados Unidos são obrigadas a oferecer oportunidades educativas iguais para seus alunos. Para além do interesse crescente e diversificação de ofertas pedagógicas, esses esforços ainda estão distantes de endereçar adequadamente práticas opressivas intersecionais e capacitistas nas salas de aula. Eu argumento por uma teorização sobre deficiências integrada no contexto do desenvolvimento e da aprendizagem, superando assim separações reducionistas, individualizantes e dicotomizadas. Amparado em Estudos Críticos sobre Deficiências, na teoria da Defectologia de Vygotsky e no Posicionamento Ativo e Transformador, o artigo apresenta uma pedagogia transformadora inclusiva, justa e anti-capacitista para todos os alunos.

Palavras-chaves: Deficiências, Pedagogia transformadora anti-capacitista, Posicionamento Ativo e Transformador.

Higher education institutions in the U.S. are legally bound to provide equal educational opportunities and inclusive learning environment for diverse learners. However, educators and administrators are struggling to come to a clear understanding of what educational equality and inclusion means and how it should be implemented. Drawing on my research on the dis/abling impact of teaching and institutional practices for a student diagnosed with autism in an urban community college (PODLUCKÁ, 2013), I review extant

\footnotetext{
1 This is an abbreviated version of the paper originally published in the 2020 Vol 21 No 1 of the Outlines: Critical Practice Studies Journal, reproduced with permission of the Outlines Journal.

2 Social Science Department at LaGuardia Community College, City University of New York; Orcid: https://orcid.org/0000-0001-8620-5936. Email: dpodlucka@lagcc.cuny.edu.
} 
practices based on current legislation for providing accommodations for students diagnosed with a disability in the context of the US higher education.

My contention is that the dominant institutional ideology utilized by practitioners and materialized in practices of Disability Student Services Office (DSSO, also frequently regarded as Accessibility Office), perpetuates students' disablement and oppressive ableist practices. The DSSO administrators and educators commonly operate from the perspectives that result in promoting individualistic, static, decontextualized understanding of learners and learning such as individualized accommodations and the concept of learning styles (LS) that has been recognized for its outdated conceptual limitations.

Aligned with the position sustained by the (Critical) Disability scholars I argue that in order to create equitable educational opportunities based on principles of social justice for students diagnosed with disabilities there is a dire need for faculty and staff to recognize disability as socially constructed. Moving their argument forward, I claim that it is crucial to conceptualize inclusive pedagogy from a critical developmental perspective that theorizes disability in the context of the dialectical relationship between learning and development. Drawing on Vygotsky's general theory of development and theory of defectology, and Stetsenko's Transformative Activists Stance approach, I outline a framework for transformative, inclusive, equitable, and anti-ableist pedagogy for all learners.

\section{Higher education institutional policies and practices}

The Federal Rehabilitation Act of 1973 and the Americans with Disabilities Act (ADA) of 1990 and 2004, under Section 504, require higher education institutions in the U.S. to provide reasonable accommodations, academic adjustments, and equal access for students diagnosed with a disability ${ }^{1}$ to all college programs and services. The initial implementation of this law was mostly concentrated on the needs of physically disabled students, such as providing ramps for wheelchair users or books in Braille for the blind. However, when the legislation was later applied to students diagnosed with invisible disabilities - the ones that are not immediately "apparent" to others (e.g. psychiatric disabilities, chronic pain, asthma,

\footnotetext{
1 Instead of using person-first language (e.g. student with disability) or identity-first language (disabled student) I use a term "student diagnosed with a disability" to emphasize the socially constructed nature of disability and marked identity that the person may or may not choose to identify with.
} 
HIV/AIDS, neurological diagnosis, autism) the very understanding of what constitutes equal access, reasonable accommodations, and academic adjustments became a controversial issue. Given the dearth of detailed guidelines, it is not surprising that the ways in which the policies and practices are interpreted and implemented in the context of providing education to students diagnosed with invisible disabilities in individual colleges vary greatly. Though all colleges and universities are required to have a DSSO or its equivalent (e.g. Accessibility Office), those offices often focus on a narrow interpretation and mechanical application of accommodation services. In order for students to receive services and assistance from the DSSO, they must provide documentation of a diagnosed disability, so they can register at the office. In other words, student access to services and support considered as any additional services, as well as academic or nonacademic support to those commonly available to any student, is contingent on disclosed and documented disability.

Therefore, one consequential implication of this legislation, or the very basis of it, is the affirmation of a disabled identity, which is reestablished and confirmed every semester in order to maintain access to services and accommodations by providing necessary documentation. It can be argued that a student has to position herself as marginalized in order to gain access to the resources, tools, and spaces needed be included in learning, which is readily available to other students.

Claiming the identity of "student with disability" is a starting position from which those students engage in learning activities which then becomes incorporated in their identity construction as learners - a "learner with disability" that is disempowering and ultimately disabling to learning (PODLUCKÁ, 2013). Quite ironically, students have to exclude themselves as non-normative learners in order to access inclusion resources.

Furthermore, in the process of claiming disability status, students are encouraged to disclose their diagnosis to administrators of the DSSO. Usually, once a student is registered and her eligibility for services is acknowledged, the student must meet with and discuss appropriate accommodations with a counselor. These are often based on the "documented needs, previous accommodations, and functional limitations of the student" as explained on college website.

The counselor then issues accommodation letters for instructors. Students diagnosed with a disability are responsible to hand in those letters to all instructors, but in order to 
protect their privacy and prevent stigmatization, they are not required to disclose their disability to instructors. However, as Barnard-Brak, Lechtenberger, and Lan (2010) note, the socio-cultural necessity of maintaining information regarding one's disability as private and confidential, "this imperative for privacy in itself implies that there's something wrong with being disabled" (BARNARD-BRAK et al., 2010, p. 421) and may be perceived and experienced as contributing to further stigmatization. Not surprisingly, research suggests that a significant number of students do not disclose their diagnosis and opt not to register with DSSO to avoid labeling and stigma associated with disability, especially invisible disability diagnosis (BARNARD-BRAK et al., 2010; COLE, CAWTHON, 2015).

\section{Individualized accommodations}

Individual accommodations, required by law, are typically provided in the form of 'reasonable accommodation' to students on an individual basis and may include extended testing time, interpreters, note taking, and other adaptive technology services. However, higher education institutions are not required to develop any special programs for disabled students or have Individualized Educational Plans ${ }^{2}$ (IEP's). Furthermore, a college student diagnosed with a disability is not only encouraged but actually expected by the institution to act independently and advocate for herself. Frequently, DSSO staff members encourage students to develop a set of self-advocacy skills and abilities, including (a) understanding their disability; (b) communicating disability (i.e. students should be able to describe how the disability limits them functionally); and (c) being proactive. Because the college student is in charge of their educational planning, they decide what is to be disclosed to parents or guardians. Although this policy positions the student as an independent self-advocate, in some situations this may disadvantage them especially if they are not used to or unable to effectively self-advocate.

The educational and life goals for students diagnosed with a disability, on which higher education institutions and DSSOs operate, aim at developing individual responsibility, self-determination, self-reliance, and, ultimately, autonomy and independence. These goals and their corollary institutional policies and practices reflect the mainstream social discourse

2 Individualized Educational Plan (IEP) - is a plan or program designed with a goal of addressing educational needs of a child who attends either elementary or secondary institution and is diagnosed with a disability. 
of independent and autonomous human being as an ideal vision for students diagnosed with disabilities. Such individualized and autonomous notion of the self, re/produced mostly by psychology and related disciplines and institutions (DANZIGER, 1990, 1997; GOODLEY, 2017; ROSE, 1998), aligns with and further promotes the neoliberal mantra of capitalism that values an able individual (GOODLEY, 2017) that is able to participate in production of surplus (EREVELLES, 2011). Despite the fact that major theories of selfhood consider the social and interdepend origins of self-development and learning (MARTIN; MCLELLAN, 2008), educational institutions and individual practitioners serving students diagnosed with disabilities continue to rely on individualistic psychologized notions of self. Hence, they focus on "fostering the independence of individual learners" (ROBERTSON, 2001, p. 122).

My contention is that transforming prevailing educational goals and ideologies, on which support to students diagnosed with disabilities are based, requires a radical epistemological shift towards a contextualized understanding of human development and the self that focuses on the social and interdependent nature of psychological processes.

\section{Practices for accommodating students diagnosed with a disability}

\section{Limited institutional support}

Individual accommodations are implemented via institutional practices designed and proposed by the DSSO. As they emphasize providing information to and communication with faculty, they decisively contribute to how instructors understand and position their students. DSSO practices are mediated by a range of resources, including information for instructors about the legal rights and responsibilities of students registered with DSSO, faculty's own rights and responsibilities, specific disability information for teaching 'students with disabilities' and suggestions and teaching strategies related to these specific diagnoses. However, due to established practices for securing confidentiality of information regarding student disability, the information that the DSSO makes available to faculty are quite limited from the point of view of faculty in need of adjusting their pedagogical practices to meet the needs of students diagnosed with a disability. 
Instructors are usually made aware of the fact that the accommodations might be determined based on the specific disability or "functional limitations" resulting from it, though neither will be disclosed to them. Instructors are informed that they are not going to be involved in the accommodation selection process. They are simply expected to provide or allow students to utilize mandated accommodations. Consequently, the very instructors who are responsible to design course curriculum, organize learning spaces in order to create opportunities to access course content and promote student's learning, are typically excluded from discussing the specific needs of students diagnosed with a disability taking their courses.

Overall, the instructors I interviewed for my research project (PODLUCKÁ, 2013) centered on examining teaching and institutional practices for a student diagnosed with autism, reported that, for various reasons, communication between them and the DSSO is more of an exception rather than regular practice. Nonetheless, they indicated that informal negotiations with the DSSO was the most effective practice to help them work with and support students diagnosed with a disability, suggesting that they would benefit from more significant support from the DSSO and the institution in general. Instructors often perceive that the institution leaves them ill equipped to design instruction and utilize effective accommodations for students diagnosed with a disability. As a result, they face tensions in their efforts to adjust teaching practices based on such limited necessary institutional support. It is problematic for instructors to provide accommodations relevant to a specific disability without trying to monitor, observe or identify students' 'symptoms' themselves. Such attempts can easily lead to the risk of misinterpreting and neglecting to accommodate students' actual needs as well as stigmatizing and subjecting students to ableism.

In sum, the ability of the DSSO to attain its official goal to support students and faculty is quite limited. In reality, the DSSO operates predominantly as a merely administrative body, managing students registered with the DSSO.

\section{The persistence of learning styles}

DSSOs commonly make available pedagogical recommendations and suggestions for faculty teaching those students. As I quickly learned while interacting with the staff from the DSSO and reading the materials they provide to faculty (PODLUCKÁ, 2013), recommendations and support for instructors are typically based on the notion of learning 
styles. This was corroborated by reviewing pedagogical recommendations in different US colleges. Its widespread use is particularly alarming given that the concept has been thoroughly criticized as oppressive and discriminatory due to its individualistic and decontextualized connotation of learners and the learning process (REYNOLDS, 1997; GUTTIEREZ and ROGOFF, 2003).

The concept of learning styles, represented in a range of theories and inventories, refers to the notion that learners have an individual style of learning understood as a stable characteristic. An abundance of critical and systematic reviews have demonstrated that the theoretical construct of learning styles does not fit with and in fact clashes with most commonly accepted constructivist and sociocultural theories of learning and development due to its theoretical incoherence, low reliability, poor validity and "minimal impact on teaching and learning" (COFFIELD, et al., 2004; PASHLER, et al., 2008).

Paradoxically, the still growing influence of learning styles as guiding principle for developing instructional support especially for students diagnosed with invisible disabilities, can be traced to the well-intentioned efforts concerned with rejecting a deficit view of disability. Drawing on the recently emerging movement of neurodiversity and on the social model of learning difference, proponents of this notion call for understanding invisible disabilities as 'neurological differences' (LAWSON, 2006; POLLACK, 2009). My contention is that such claims deserve careful scrutiny. To be sure, efforts of applying the concept of neurodiversity in higher education should be commended for attempting to contribute a positive view of students diagnosed with neurological diagnoses by (a) emphasizing social and therefore anti-deficit view of disability, (b) valuing the neurological diversity of students contributing to body of learners and teaching process, (c) promoting implementation of rules and tools of Universal Design for Instruction and other nontraditional methods of instruction and assessment, and (d) increasing awareness of neurodiversity and embracing it as a part of human diversity. However, though advocates of the neurodiversity approach endorse the social model of disability, thus rejecting in principle individualistic views of disability (and of human nature in general), they nonetheless contradict their own efforts as they unwittingly continue to rely on individualistic notion of human mind and learning.

This is clearly manifested in reductionist claims, central to the position that we should speak of 'difference' rather than 'disability', that a different type of brain results in different 
cognitive processing that consequently leads to different learning styles. Although the concept of neurodiversity has undeniably played a pivotal role in forming a societal "counternarrative" in the "process of cultural critique and resistance to ideological hegemony" (BRODERICK; NE'EMAN, 2008, p. 459), it is necessary to recognize its limitations and to fully acknowledge its potentially harmful implications, especially if implemented in educational practice.

In my view, using neurodiversity to view students diagnosed with autism, or other 'neuro-atypical' learners as essentially having different brains and, consequently corresponding different learning styles, amounts to an oversimplified and de facto reductionist view of the learners and the process of learning itself. This view is essentially relying on a cognitivist view of 'neurological differences' that sustains locating them in the individual's brain. Arievitch (2017), in his eloquent discussion of the inadequacy of neuro-explanations in education, points out that learning cannot be explained exclusively in terms of neural mechanisms - as in theories that describe abnormalities in brain wiring in autism. As he argues, while "brain functions create the necessary physiological support for the mind, these functions can neither determine nor "explain" the mind" (ARIEVITCH, 2017, p. 22). As an illustration, Arievitch explains that while it may be "possible to describe what is going on in the brain when an individual buys something, or when an individual decides whether someone is guilty of some wrongdoing," it is nevertheless "impossible on this basis to explain the concepts of exchange value or criminal justice." (ARIEVITCH, 2017, p. 22, emphasis in the original). Rather than reducing learning and knowledge construction to patterns of firing and inhibiting groups of neurons, genuinely "explaining" mental processes such as learning requires addressing "the agent's activity in the world" (ARIEVITCH, 2017, p. 23). This is what McDermott (1993) accomplished in his now classic description of "The acquisition of a child by a learning disability". Rather than locating the disability in the depths of the child's brain, McDermott describes it as emerging from the situated dynamics of the child's interactions with teachers and peers mediated by specific cultural tools, including diagnostic discourses and pedagogical practices, in the context of an after-school program.

My contention is that if we continue to design our educational practices on such outdated understanding of the human mind as locked inside of heads of our students, and remain stubbornly focused on individual students, we will continue failing and disabling all of 
our students, regardless of treating their brains as "different" or "disabled". Such narrow understandings of 'neurological' or other cultural difference as an individualistic trait leads to what Gutiérrez and Rogoff (2003, p. 19) recognize as:

\begin{abstract}
strategy of locating characteristics separately in the person and in the "context," and "crossing" style and context as in the Aptitude X Treatment approach. In educational settings, work on learning styles has often attempted to take context into account by seeking style matches between students and schooling experiences or between student and teacher (Banks, 1995). However, some applications of this approach are based on an assumption that an individual's "style" is a trait that is independent of task and context, and that is constant over time. Such a matching strategy does not account for change- in the individual, the activity setting, or the community-and it assumes one style per person according to the individual's group categorization. $^{3}$
\end{abstract}

Reynolds (1997) points out the danger of such student-dependent and decontextualized understandings of learning and pedagogy and argues that the "very concept of learning styles obscures the social bases of difference expressed in the way people approach learning", which provides "discriminatory basis for dealing with difference in gender or race" (REYNOLDS, 1997, p. 122). Indeed, the learning styles concept has been used by psychologists as a discriminatory and ableist tool to explain 'cognitive deficit' and 'academic failures' in 'minority students' (for critique see FOLEY, 1997; IRVINE; YORK, 1995; MCCARTHY et al., 1991). However, though the learning style concept "deflects attention from the larger social system as a determinant of inequality", it remains attractive because "it appears to be humanistic, concrete, direct and immediate" (SARUP, 1986, as cited in REYNOLDS, 1997, p. 125).

The learning style concept wrapped in the discourse of promoting difference, diversity, and inclusion appeals to well-meaning education professionals because it seems to offer them guidance in developing inclusive teaching and institutional practices. School counselors and staff supporting students diagnosed with invisible disabilities are recommended to employ learning styles-based assessment instruments to facilitate transitioning from high school to college, including identifying students' learning styles so they can become more independent and advocate for themselves in college (KRELL; PÉRUSSE, 2012; ROBERTS, 2010). What usually escapes their scrutiny is how this concept

3Banks, J. A. (Ed.). Handbook of research on multicultural education. New York: Macmillan, 1995. 
fits neatly in the neoliberal discourses that promote a business model of education couched in notions of individualism and independence, which feeds into the blooming industry of publishing learning styles assessment tests and guides for educators. The upshot is that conventional college support practices for students diagnosed with disabilities continue to be grounded in outdated individualistic, deficit-driven medical models, which perpetuates the understanding of disability as an individual characteristic of the learner.

Expanding inclusive education beyond accessibility and disability rights: Addressing disability from a social justice perspective

With the increasing diversification of higher education student populations, educators recognize the limitations of accommodations geared exclusively towards individual learners diagnosed with disabilities. The search for a more inclusive and equitable pedagogy has made some approaches, such as the Universal Design (UD) based frameworks to learning increasingly popular (see MCGUIRE, 2014 for the review). These approaches apply principles of UD, originally developed in architecture, to education and learning contexts to enhance accessibility of learning instructions to all learners, including students diagnosed with disabilities, by designing and delivering instruction by identifying and eliminating unnecessary barriers to teaching and learning while maintaining academic rigor (BURGSTAHLER, 2015).

Unfortunately, many educators and service providers understand UD frameworks as a practical extension to learning styles, as a set of tools that "acknowledge the different learning styles of students in the classroom and encourages teachers to create flexible approaches to learning that can accommodate many students' learning styles" (WILLIAMS, 2016, p. 48). Furthermore, although UD frameworks challenge the uniformity of pedagogy, authors such as Waitoller and Thorius (2016) have pointed out that they do not allow for dismantling the prevailing ableism and other forms of oppression in educational practices. Hence, they propose a 'cross-pollination' between Universal Design for Learning (UDL) and Culturally Sustaining Pedagogy (CSP) (PARIS, 2012; PARIS; ALIM, 2014), as the latter was developed to "account for students dis/ability in addition to race, ethnicity, language, and class" and "dismantle intersecting and compounding forms of exclusion" (WAITOLLER; THORIUS, 
2016, p. 368). According to them CSP is crucial to inclusive pedagogy as it sustains (i.e., supports and fosters) "linguistic, literate, and cultural pluralism as part of a democratic project of schooling" (PARIS, 2012, p. 95). Importantly, CSP calls for all involved in the education process to reflect on their own cultural practices that might be oppressive to other groups and reproduce hegemonic oppression such as sexism, ableism, homophobia and racism.

Disability studies and critical theory scholars have long pointed out that learning and development, especially in students diagnosed with disabilities, is hindered by ableism, frequently intersecting with racism, sexism, classism, and other discriminatory and oppressive practices (ALIM et al., 2017; BRODERICK; LALVANI, 2017; CONNOR et al., 2016; GABEL; CONNOR, 2014). Though the need to address disability has given rise to the notion of inclusive education, underpinned by a social justice ethos, historically, disability has been systematically excluded from the discourses of social justice and diversity (BUFFINGTONADAMS; VAUGHAN, 2019; GIBSON, 2015; LIASIDOU, 2014), intersectionality (EREVELLES; MINEAR, 2010; NOCELLA, 2009), and critical perspectives of education (ANDERSON, 2006; EREVELLES, 2000; GOODLEY, 2007; LIASIDOU, 2012). Thus, Disability and Critical studies scholars have called for understanding inclusive education as a political process (DOLMAGE, 2017; GIBSON, 2015) that engages in dismantling social injustices and challenges the status quo and normative practices (BURKE, 2012). In addition, I suggest that such critical analysis also needs to be incorporated into the teaching agendas of all postsecondary educators, not just in the curriculum for student teachers in training or Disability Studies programs. This is in consonance with disability scholars who propose to incorporate Disability Studies into the curriculum in US schools (BAGLIERI; SHAPIRO, 2012; GABEL; CONNORS, 2009). Systematic recognition and interrogation of intersecting oppressive practices must become an integral part of college education so students can understand, actively challenge and resist ableism and other structural inequities of social order. Importantly, a truly transformative inclusive education moves beyond helping students to recognize social injustices by providing them with tools of agentive and activist positioning to challenge and resist ableism and other systems of oppression in which we are all implicated, participate in, and contribute to.

In addition, preparing faculty to develop inclusive pedagogies requires broadening current forms of institutional support beyond the narrow focus on (a) increasing awareness of 
disability and developing positive attitudes toward students' diagnosed with a disability (AVRAMIDIS; NORWICH, 2002; HONG; HIMMEL, 2009; LEYSER; GREENBERGER, 2008; LOVE et al., 2014); and (b) providing professional development for faculty on disability issues and inclusive education (DEBRAND; SAZBERG, 2005; DAVIES et al., 2013) and implementing UDL strategies in teaching (BLACK; WEINBERG; BRODWIN, 2014).

Inclusive education has also been influenced by the disability rights movement. Recently, scholars have called for expanding this movement with a focus on learning from and with students diagnosed with disabilities. According to Gibson (2015) their experiences constitute an invaluable source of knowledge for educators who seek to design and implement inclusive pedagogy. I fully concur that the experiences of students diagnosed with disabilities should undoubtedly be considered as constitutive elements of creating inclusive higher education institutions and challenging ableist practices. Nonetheless, I argue, that in order to develop a truly inclusive, equitable, socially just and transformative pedagogy, we need a theory that posits disability in the context of learning and development, a theory that integrates disability into human development in a manner that overcomes dichotomized and reductionist perspectives of disability and individualistic notions of learning (PODLUCKÁ, 2013).

\section{Toward a transformative activist anti-ableist pedagogy}

In articulating the principles for an inclusive transformative pedagogy, I draw on Vygotsky's general theory of development (1978; 2004), his theory of defectology (1993), and on Stetsenko's (2016) Transformative Activist Stance (TAS).

\section{Vygotsky's socio-cultural theory of development and theory of defectology}

Vygotsky suggests that social interactions mediated by cultural tools are the source and foundation of human development, which is dialectically connected with learning as interdependent processes, fundamentally social and collaborative in their nature (VYGOTSKY, 1978). This dialectical unity of learning and development posits learning as a leading force of development, and a process of identity making. Therefore, learning is central 
to understanding student development. Consequently, a pedagogy that makes a promise of inclusion and commits to equity requires that we take into consideration the dynamic, dialectical and intersecting relationships between learning, self and disability. Vygotsky's theory of defectology ${ }^{4}$ (1993), also referred as theory of disontogenesis, which focuses specifically on the development of cognitively and physically disabled children, is of particular relevance. It is important to note that both Vygotsky's general theory of development and his theory of defectology are the result of his deep social commitment and engagement with the most disadvantaged members of society, such as homeless and disabled children (STETSENKO; ARIEVITCH, 2004). His involvement with his society, its old and emergent issues, together with his commitment to building a new, just society were materialized in this (till this day) revolutionary understanding and explanation of human development. It is no surprise that one of the most important assets of his theory, although often overlooked in many of its modern interpretations, is the commitment to social justice.

This point is extremely important as it converges with the focus of disability studies on the inclusion of disabled persons, which is ultimately an issue of social justice. Regarding the development of disabled children, Vygotsky provides a theoretical explanation of why, for them, equal access to cultural tools that allow for participation in and contribution to collective activities is not only a matter of human rights, or merely an opportunity that might enhance development, but rather these are necessary and constitutive forces and conditions of development. The fundamental principles of Vygotsky's defectology (1993) is understanding the development of a disabled child from a positive differential approach. Specifically, he argued for disability to be understood and approached as a different path of development and becoming, rather than deficiency of normalcy. This point is complementary with a positive view of disability championed by Disability Rights Movements and Disability Studies scholars that is in contrast with the traditional positioning of children diagnosed with disabilities as deficient and pathologized individuals (GIBSON, 2015).

\footnotetext{
4 The language used by Vygotsky to refer to disability, disabled children, and their development appears outdated. For a reader in the $21^{\text {st }}$ century might seem to reflect a deficit model of disability. However, it is important to read his work within the historical context and keep in mind that Vygotsky wrote a theory of defectology in the early $20^{\text {th }}$ century, when such terminology was a common (and the only available) practice. When I wrote about his theory, I made an effort to change and update the original language as much as possible, while maintaining the original meanings. I kept the original expressions (e.g. "abnormal child") when directly quoting Vygotsky. For more on the terminology see Gindis (1994, 2003).
} 
One of the most important contributions of Vygotsky's theory of defectology (1993), and principle based on which inclusive pedagogy can be based, is his dynamic conceptualization of disability based on distinguishing between primary and secondary causes and impairments. This distinction provides a theoretical explanation for how disability is socially constructed from a psychological perspective. Vygotsky (1993) proposed that the primary impairment is an organic one, due to either endogenous and exogenous biological causes. The secondary impairment refers to a consequent alteration of higher psychological functions (e.g. abstract reasoning, logical memory, voluntary attention, etc.) that results from the interaction of the primary impairment with the social environment of the disabled child. The primary, organic impairment can prevent a child from mastering some social skills and knowledge, which usually leads to irregular or what would be considered delayed development. However, Vygotsky argued that many of the resulting symptoms are of a secondary nature, as they are acquired in the process of social interactions. As Vygotsky emphasized, it is the child's social milieu, including social interactions and cultural tools available (or not) to the child, not the organic impairment per se, that alter the child's development and results in disontogenesis ("defective" development). Obviously, the quality and accessibility of social interactions and cultural tools mediating all the activities of the child are of utmost importance for her development.

As Vygotsky emphasized, the distinction between primary and secondary causes of developmental impairments is not simply of theoretical interest, but has profound implications for intervention, and education in particular, because its secondary complications and delays are more responsive to therapeutic pedagogical activity- unlike organic conditions that cannot be eliminated. Therefore, the focus for educators' endeavor to create an inclusive pedagogy should always be providing support that would address, and possibly prevent, the secondary causes of the learner's disablement. Furthermore, Vygotsky (1993) suggested that positive differential approach represented understanding disability as a unique rather than deficient path of development that requires diversified and adequate cultural tools materialized in a special system of cultural signs and symbols adapted to the specific psychophysiological characteristics of a developing child. Vygotsky attributed a prominent role to cultural tools in human learning and development, in his own words: 
[I]n order that the child mediates, makes sense of, and interacts in a meaningful way with the environment, he or she must have access to and acquire a multitude of psychological tools or artificial, historically developed, cultural signs available to shape and organize the world (VYGOTSKY, 1993, p. 15).

Vygotsky further points out that because most of the psychological tools are designed for the typically developing person with all senses and mental functions in principle intact, "special psychological tools must be developed for the abnormal child which focus on his or her other healthy functions and residual strength" (VYGOTSKY, 1993, p. 15). The implication here is that all children, with or without biological impairment, follow the same general principles and laws of development and education. Consequently, the psychological nature of instruction should be identical. However, the techniques for instructing a child must differentiate depending on the nature of her impairment. The meaning of the tool and the goal of the psychological function to be developed by mastering the tool is the same for typically and atypically developing children. However, the technical shape and the actual type of tool is different and must be adapted to, and be in congruence with the impairment, so the mediation of a cultural and/or psychological meaning is possible.

Vygotsky's articulation of the pivotal role and the meaning of cultural tools in learning and development suggest that while learners diagnosed with a specific disability would benefit from tools, including specific devices, instructions and other accommodations designed as disability specific (e.g. a specific mode of communication such as Braille or sign language), the function and the meaning of the tools (e.g. facilitation of communication) is identical for all learners. This point serves as an important guide for designing curriculum, teaching instructions and for providing accommodations for students diagnosed with disabilities because it addresses a common reservation among educators about lowering the expectations and watering down the content.

Furthermore, Vygotsky repeatedly emphasized that in order to truly understand the child's complex developmental path, the socio-cultural and historical contexts in which it occurs must be considered as constitutive forces, rather than additive factors. He called for understanding the disabled child as a complete being, focusing on his or her entire personality, rather than on isolated impairments and diagnosed disabilities. In addition, Vygotsky warned that focusing on "defects" themselves does not produce understanding of neither the "defect" nor the child. Rather, we need to view development as context-dependent 
and focus on the dialectical relationship between the impairment and the child's personality (i.e., the socio-psychological realization of disability). It is impossible to understand the impairment itself unless it is studied in connection to psychological structures and the child's personality, what for Vygotsky means the system of activities and hierarchy of motives in which the defect enters. This point further illustrates the dialectical unity of disability, learning and development.

The overarching idea of Vygotsky's disontogenesis can be summed up in a single statement that the child, even if born with impairment, only becomes disabled in the process of her development. Disability, just as the self, mind, as well as all psychological functions, originates and develops in human activity, always mediated through cultural tools. Therefore, the extent of a learner's disablement is understood as a result of lacking or inadequate cultural tools and/or social interactions through which the tools are introduced, not the "deficiencies" of the individual. Vygotsky, in his theory explains that depending on the organization of social practices in which a child (with impairment) participates and engages in, and the cultural tools available to her, the child can achieve different levels of development. Consequently, the principal role of education is to create opportunities that will promote learners' engagement and mastery of cultural tools and practices. Vygotsky's conceptualization of development and learning, the role of social interactions and cultural tools in human development, clearly point out to the roots of inequality and exclusion in education, and provide a framework for creating socially just inclusive pedagogy.

\section{Transformative activist stance based pedagogy and its implications}

Expanding on Vygotsky's ideas, the Transformative Activist Stance provides the theoretical grounding to further elaborate an inclusive transformative pedagogy based on principles of social justice (STETSENKO, 2008, 2014, 2016, 2017). The fundamental principle advanced by the TAS that offers further guidance for inclusive pedagogy is that all humans are "equal in their core capacities" and that all persons have "infinite potential" for development. Such open-ended, dynamic understanding of human development and learning posits all learners, including those who have traditionally been excluded from education, as capable of learning with infinite potential to change. 
In sharp contrast views of the learner as a solitary, independent and autonomous entity, the TAS posits human development and learning to be grounded in unique agentive contributions to transformative collaborative activities through which a person participates, engages and contributes to social practices, thus transforming those practices and oneself in the process (STETSENKO, 2014). This notion of individual contribution challenges the traditional dichotomy of social and individual as "contribution is something that individuals do but only as members of their communities who are fully immersed in social collaborative practices" (STETSENKO, 2010, p. 9). According to this view, the key role of teaching and learning is to create opportunities for individuals to acquire the cultural tools (e.g. scientific concepts) that allow learners to contribute to social practices and society (STETSENKO, 2008). Hence, the role of the educator is to facilitate students' mastery, creation, and transformation of cultural tools; the tools of their own development that enable them to position themselves and act as agents of change in their professional communities and cultural worlds. The TAS further emphasizes that this change is always oriented towards the future, as every knowledge and its construction arrives from "a particular historical location" and from within leaners" "agendas and visions for the future" (STETSENKO, 2014, p. 195). These agendas, always located in the past and present and oriented towards the future, involve taking an activist stance of "how present community practices ought to be changed and, thus what kind of future ought to be created" (STETSENKO, 2014, p. 192, emphasis in the original).

Accordingly, a TAS-based pedagogy conceives of the curriculum in terms of providing tools of agency (STETSENKO, 2016; VIANNA; STETSENKO, 2019) with which students can explore, interrogate and destabilize inequalities, including intersecting oppressive practices that students are subjected to, or otherwise participate in or contribute to. As a result, students are viewed not merely as consumers of an accessible curriculum, as is often the case in implementation of UD instructions in the absence of a broader pedagogical framework that clearly specifies how teaching, learning and development are connected. Rather, according to the TAS, students are positioned as activist agents engaged in cocreating the conditions of their own learning in inclusive classroom environments and building inclusive and equitable communities (STETSENKO, 2016). Such activist positioning of students is particularly important to students diagnosed with disabilities, who have 
traditionally been treated as objects of education (DOLMAGE, 2017). Indeed, a TAS based pedagogy positions all learners as contributors to collaborative practices, social change, and their own learning and development. Instead of merely giving a nod to diversity, which is often addressed as an add-on to currently existing educational practices through accessibility efforts, diversity is at the core (or the very fabric) of a TAS-based pedagogy insofar as it is interdependently realized by the unique contribution of each and all students.

Furthermore, the notion of a learner (and teacher) actively taking a stance towards the future-in-the-making distinguishes a TAS-based pedagogy from asset and emancipatory pedagogies, including culturally sustaining pedagogy (CSP). CSP focuses on sustaining cultural pluralism, for example, by interrogating and critiquing "the simultaneously progressive and oppressive currents in [...] youth practices" (ALIM, 2011, p.93 apud WAITOLLER; THORIUS, 2016). While fully concurring with this view, I contend that the importance of critique notwithstanding it needs to be complemented with more agentive and activist emphasis on transforming community practices, including teaching-learning, through spurring learners' agency.

Importantly, the TAS highlights human agency as socially, collectively and historically constructed. This fundamental point seems to get lost when the agency and subjectivity of disabled people are considered, and those diagnosed with intellectual disabilities in particular, as these concepts are usually replaced by the individualized, decontextualized and a-historical notions of the self and disability (GOODLEY, 2017). Opposition to such limited reading of agency, and of subjectivity and disability, is also echoed by Critical Disability Studies scholars. For instance, Erevelles (2005) calls for a 'reconfiguration' of human agency in relation to disability, which remains conceptualized in terms of normative ability, rationality and autonomy. Such non-agentic view of disabled persons has contributed to their systemic exclusion from social practices, including labor and education. It is precisely such re-configured conceptualization of agency, which is currently missing from Disability Studies and Critical Disabilities Studies scholarship, that the TAS offers.

As Stetsenko (2019) argues, the TAS counters narrow views of agency that closely align with neoliberal views that take it to be about: 
being able to effect changes that are only narrowly efficient for the goals of taking control of one's life, achieving success and other serving egoistic pursuits centered on individuals, each on their own, fitting in with the present regime of neoliberalism. In other words, this type of agency is not about efficacy and efficiency of individuals taken as autonomous entities (STETSENKO, 2019, p. 8).

Rather, radical transformative agency is realized as a "confrontation with the status quo" (STETSENKO, 2019, p. 8) in which students and teachers collaboratively engage, "as part of their struggle for a better world coterminous with their own becoming-their becoming agents of history and of the world-in-the-making" (p. 8). This recasts the goal of teaching and learning as "assisting students in developing their ability to take their own stands and stake their own claims on what is going on in the world and their communities, including their place and role in these processes", of which their lived experiences and funds of knowledge are an important part of, "while learning to matter, that is to imagine and commit to a future they come to believe is worthy a struggle." (STETSENKO, 2019, p. 10).

In my view, it is such notion of agency that is needed to more resolutely reposition disabled, as well as other marginalized and oppressed social groups of difference, as agentic and activist actors of community and social practices. As previously suggested, in order to practice a truly inclusive pedagogy and society, it is imperative to address widespread normative and ableist practices, and their intersections with other types of oppressions. Not only does a TAS based pedagogy call for creating opportunities for students diagnosed with disabilities, whose unique voices, bodies and minds have been historically and systematically ignored and excluded from contributing to learning communities. Crucially, the TAS calls for positioning them as experts of their lives who have intimate knowledge of ableism and disableism. Critically, this pedagogy is not about a superficial tokenistic way of allowing students with disabilities to participate, voice their stories, and be tolerated in the classrooms. It is about an opportunity for able-bodied learners to learn from and with those who are the most marginalized, in and outside of the classrooms, and whose experiences and knowledge are essential in our struggles against alarming disparities in education and other areas of the society. Their marginalized positions, stories of discrimination, and their knowledge of reality and the extent of everyday oppression are central to our understanding of conflicts and contradictions, how to resist, overcome and change social inequalities. 


\section{Conclusion}

This paper reviews institutional policies and current practices for providing support for students diagnosed with a disability common to higher educations in the U.S. and discussed key gaps and contradictions in how they are typically implemented. Examination of the institutional processes that the students diagnosed with disabilities undergo in order to gain access to learning revealed that some higher education institutional policies and practices aimed at enabling accessibility of learning re/produce ableism and position students as 'disabled'. It also disclosed that learning styles concept are still the common basis for interpreting disability and providing instructional support in higher education. I propose to move away from these practices that rely on individualized notion of learning and learners. While acknowledging the value of Universal Design for Learning and Culturally Sustaining Pedagogy for enhancing accessibility of learning and promoting inclusion of diverse learners, I call for moving beyond these approaches towards transformative pedagogy.

The focal goal of this paper is to contribute to a conversation about what transformative pedagogy for inclusive, equitable, and anti-ableist education for all learners might look like. Though this is undoubtedly a daunting task, I propose that in order to develop a truly inclusive, transformative and socially just pedagogy it needs to be based on a developmental perspective that posits disability in the context of a dialectical and dynamic relationship between learning and development and breaks away from individualistic and reductionist notions of learner, learning and disability.

In addition to pedagogy, the practices and policies, including educational goals and ideologies on which education and support to students diagnosed with are formulated, require a radical epistemological shift towards an interdependent, contextual and dynamic understanding of learning, human development and agency. Consequently, in our efforts of developing and practicing inclusive pedagogy we need to shift our attention from individual learners to learning as a collective and collaborative activity. Vygotsky's general theory of development, and his theory of defectology in particular, provide a strong foundation for inclusive pedagogy by explaining psychological and developmental disability and disablement as socially constructed. He also made clear that the foremost role of educators is to promote students' development of higher mental functions by providing them with differentiated instructions and other culturally mediated tools. Importantly, as Vygotsky 
pointed out, given the socio-cultural origins of development, educators can (and should) focus on limitless opportunities for students' development instead of students' impairments.

Stetsenko's further expansion of the Vygotskian project with TAS approach provides a road map for inclusive pedagogy by pointing to the infinite human potential to change and contribute, independently or interdependently, to transformative collaborative activities. Based on the TAS, the proposed transformative pedagogy positions all students as agents of change within the teaching/learning process in reciprocal, mutually constitutive manner. Importantly, the teaching/learning process is not organized as a purely abstract intellectual endeavor distanced and separated from the real life of students and their communities. Quite the opposite, a TAS-based pedagogy suggests that we design and practice teaching and learning as a process of promoting and developing students' and teachers' radicaltransformative agencies, understood as collectively and historically constructed in the process of collaborative engagement against the status quo while employing critical-theoretical tools of the corresponding disciplines. Ineluctably, a transformative pedagogy represents a political process rather than one of acquisition of neutral and objective information. According to this view, issues of social justice and diversity, including disability, must be infused into curriculum of all disciplines for all learners. A socially just, anti-ableist, transformative pedagogy invites students and teachers of all disciplines to interrogate the ethico-political underpinnings of competing disciplinary knowledge, thus collaboratively and agentively engage in the exploration of how their fields contribute to addressing, either transforming or re/producing social, economic, cultural, environmental and other inequalities. ${ }^{5}$

\section{References}

ALIM, H. S. et al. Responding to "cross-pollinating culturally sustaining pedagogy and universal design for learning: Toward an inclusive pedagogy that accounts for dis/ability". Cambridge, UK: Harvard Educational, 2017.

\footnotetext{
${ }^{5}$ I would like to thank to my colleagues and friends, Drs. Debbie Sonu, Brooke Schreiber, Dina Lopez, Eldar Sarajlic, Robin Ford, Tiffany DeJaynes, and Yasmin Morales-Alexander, members of the City University of New York Faculty Fellowship Publication Project, who provided me with encouragement and invaluable comments on early draft of this paper. I would also like to thank to Dr. André Luis Leite for editing the original version of this paper published in Outlines: Critical Practice Studies.
} 
ANDERSON, R. C. Teaching (with) disability: Pedagogies of lived experience. The Review of Education, Pedagogy and Cultural Studies, [S.1.], v. 28, n. 3-4, p. 367-379, 2006.

ARIEVITCH, I. M. Beyond the brain: An agentive activity perspective on mind, development, and learning. [S.1.]: Springer, 2017.

AVRAMIDIS, E.; NORWICH, B. Teachers' attitudes towards integration/inclusion: A review of the literature. European journal of special needs education, [S.1.], v.17, n. 2, p. 129-147, 2002.

BAGLIERI, S.; SHAPIRO, A. Disability Studies and the Inclusive Classroom: Critical practices for creating least restrictive attitudes. Abingdon: Routledge, 2012.

BARNARD-BRAK, L.; LECHTENBERGER, D.; LAN, W. Y. Accommodation strategies of college students with disabilities. The Qualitative Report, [S.1.], v. 15, n. 2, p.411-429, 2010.

BLACK, R. D.; WEINBERG, L. A; BRODWIN, M. G. Universal design for instruction and learning: A pilot study of faculty instructional methods and attitudes related to students with disabilities in higher education. Exceptionality Education International, [S.1.], v. 24, n. 1, p. 48-64, 2014.

BRODERICK, A.; NE'EMAN, A. Autism as metaphor: narrative and counter-narrative. International Journal of Inclusive Education, v. 12, n.5-6 , p. 459-476. 2008.

BRODERICK, A.; LALVANI, P. Dysconscious ableism: toward a liberatory praxis in teacher education. International Journal of Inclusive Education, v. 21, n.9, p. 894-905. 2017.

BUFFINGTON-ADAMS, J.; VAUGHAN, K. P. The Curriculum of Disability Studies: Multiple Perspectives on Dis/ability. Introduction: An invitation to complicated conversations. Journal of Curriculum Theorizing, [S.1.], v. 34, n.1, 2019.

BURGSTAHLER, S. E. Universal design in higher education: From principles to practice. Cambridge, UK: Harvard Education Press, 2015.

COFFIELD, F.; MOSELEY, D.; HALL, E.; ECCLESTONE, K. Learning styles and pedagogy in post-16 learning: A systematic and critical review. London: Learning and Skills Research Centre, 2004.

COLE, E. V.; CAWTHON, S. W. Self-Disclosure decisions of university students with learning disabilities. Journal of Postsecondary Education and Disability, [S.1.], v. 28, n.2, p.163-179, 2015.

CONNOR, J. D.; FERRI, B.; ANNAMMA, S. A. DisCrit: Disability studies and critical race theory in education. Columbia: Teachers College Press, 2016.

DANZIGER, K. Constructing the subject: Historical origins of psychological research. Cambridge, UK: Cambridge University Press, 1990. 
DEBRAND, C. C., SALZBERG, C. L. A Validated Curriculum to Provide Training to Faculty regarding Students with Disabilities in Higher Education. Journal of Postsecondary Education and Disability, [S.1.], v. 18 n. 1, p.49-61, 2005.

DOLMAGE, J. T. Academic ableism: Disability and higher education. Ann Arbor, MI: University of Michigan Press. 2017.

EREVELLES, N. Educating unruly bodies: Critical pedagogy, disability studies, and the politics of schooling. Educational theory, [S.1.], v. 50, n. 1, p. 25-47, 2000.

EREVELLES, N. Rewriting critical pedagogy from the periphery: Materiality, disability and the politics of schooling. In: GABEL, S. (ed.). Disability studies in education: Readings in theory and method. Bern: Peter Lang, 2005, p. 65-83, v.3.

EREVELLES, N. Disability and difference in global contexts: Enabling a transformative body politic. [S.1.]: Springer, 2011.

EREVELLES, N.; MINEAR, A. Unspeakable offenses: Untangling race and disability in discourses of intersectionality. Journal of Literary \& Cultural Disability Studies, [S.1.], v.4, n. 2, p. 127-145, 2010.

FOLEY, D. E. Deficit thinking models based on culture: The anthropological protest. In. R. Valencia. The evolution of deficit thinking: Educational thought and practice. Washington, DC: Falmer Press, 1997.p. 113-131.

GABEL, S.; CONNOR, D. Disability and Teaching. New York, NY: Routledge. 2014.

GABEL, S. L.; CONNOR, D. J. Theorizing disability: Implications and applications for social justice in education. In: Handbook of social justice in education. Abingdon: Routledge. 2009. p. 395-417.

GIBSON, S. When rights are not enough: What is? Moving towards new pedagogy for inclusive education within UK universities. International Journal of Inclusive Education, [S.1.], v.19 n. 8, p. 875-886, 2015.

GINDIS, B. Vygotsky's defectology. American Journal on Mental Retardation, [S.1.], v. 100, n. 2, p.214-216, 1994.

GOODLEY, D. Towards socially just pedagogies: Deleuzoguattarian critical disability studies. International journal of inclusive education, [S.1.], v.11, n.3, p. 317-334, 2007.

GOODLEY, D. Disability studies: An interdisciplinary introduction. London: Sage, 2017

GUTIÉRREZ, K. D.; ROGOFF, B. Cultural ways of learning: Individual traits or repertoires of practice. Educational Researcher, [S.1.], v. 32, n. 5, p.19, 2003.

HONG, B. S.; HIMMEL, J. Faculty attitudes and perceptions toward college students with disabilities. College Quarterly, [S.1.], v.12, n.3, p. 678-684, 2009. 
IRVINE, J. J.; YORK, D. E. Learning styles and culturally diverse students: A literature review. In BANKS, J. A. (ed.). Handbook of research on multicultural education. New York: Macmillan. 1995. p. 484-497.

KRELL, M., PÉRUSSE, R. Providing college readiness counseling for students with autism spectrum disorders: A Delphi study to guide school counselors. Professional School Counseling, v. 16 n. 1, p.29-39, 2012. DOI 10.5330/PSC.n.2012-16.29.

LAWSON, W. Typical development, learning styles, single attention and associated cognition in autism (SAACA). Good Autism Practice, [S.1.], v. 7, n. 2, p. 61-71, 2006.

LEYSER, Y.; GREENBERGER, L. College students with disabilities in teacher education: Faculty attitudes and practices. European Journal of Special Needs Education, [S.1.], v.23, n. 3, p. 237-251. 2008.

LIASIDOU, A. Inclusive education and critical pedagogy at the intersections of disability, race, gender and class. Journal for Critical Education Policy Studies, [S.1.], v.10, n.1, p.168184, 2012.

LIASIDOU, A. Critical disability studies and socially just change in higher education. British journal of special education, London, v. 41, n.2, p.120-135, 2014.

LOVE, T. S. et al.. STEM Faculty experiences with students with disabilities at a Land Grant Institution. Journal of Education and Training Studies, [S.1.], v. 3 n. 1, p.27-38, 2014.

MARTIN, J.; MCLELLAN, A.M. The educational psychology of self-regulation: A conceptual and critical analysis. Studies of Philosophy and Education, [S.1.], v.27, p. 433-448, 2008.

MCCARTHY, T.L.; LYNCH, R.L., WALLACE, S.; BENALTY, A. Classroom Enquiry and Navajo Learning Styles: a Call for Reassessment. Anthropology and Education Quarterly, [S.1.], v. 22, p. 42-59, 1991.

MCDERMOTT, R. P. The acquisition of a child by a learning disability. In CHAIKLIN, S.; LAVE, J (ed.). Understanding practice: Perspectives on activity and context. Cambridge, UK: Cambridge University Press. 1993. p. 269-305.

MCGUIRE, J. M. Universally accessible instruction: Oxymoron or opportunity? Journal of Postsecondary Education and Disability, [S.1.], 27, n. 4, p. 387-398, 2014.

NOCELLA, I. J. Disabling Dis-ability: Re-building inclusive into social justice. Theory In Action, [S.1.], v. 2, n. 1, p. 140-157, 2009. DOI 10.3798/tia.1937-0237.08033

PARIS, D. Culturally sustaining pedagogy: A needed change in stance, terminology, and practice. Educational researcher, [S.1.], v. 41, n. 3, p. 93-97, 2012. 
PARIS, D.; ALIM, H. S. What Are We Seeking to Sustain through Culturally Sustaining Pedagogy? A Loving Critique Forward. Harvard Educational Review, [S.1.], v. 84, n.1, p. 85$100,2014$.

PASHLER, H., MCDANIEL, M., ROHRER, D., BJORK, R. Learning Styles. Concepts and evidence. Psychological Science in the Public Interest, [S.1.], v. 9, n. 3, p. 106-119, 2008.

PODLUCKÁ, D. Dis/Abling a learner diagnosed with autism: The dialectics of learning and development in higher education. Ann Arbor, MI: ProQuest, 2013.

POLLACK, D. Neurodiversity in higher education: Positive responses to specific learning differences. Malden, MA: John Wiley and Sons. 2009.

ROBERTS, K. D. Topic areas to consider when planning transition from high school to postsecondary education for students with Autism Spectrum Disorders. Focus On Autism And Other Developmental Disabilities, [S.1.], v. 25, n. 3, p. 158-162, 2010.

ROBERTSON, C. Autonomy and identity: The need for new dialogues in education and welfare. Support for Learning, [S.1.], v. 16, n.3, p. 122-127, 2001.

ROSE, N. Inventing ourselves: Psychology, power, and personhood. Cambridge, UK: Cambridge University Press. 1998.

SARUP, M. The Politics of Multiracial Education. London: Routledge \& Kegan Paul. 1986.

STETSENKO, A. Teaching-learning and development as activist projects of historical Becoming: expanding Vygotsky's approach to pedagogy. Pedagogies: An International Journal, [S.1.], v.5, p. 6-16, 2010.

STETSENKO, A. From relational ontology to transformative activist stance: Expanding Vygotsky's (CHAT) project. Cultural Studies of Science Education, [S.1.], v. 3, n.2, p. 471491, 2008.

STETSENKO, A. Transformative activist stance for education: Inventing the future in moving beyond the status quo. In CORCORAN, T. (ed.). Psychology in Education: Critical Theory Practice. Rotterdam, The Netherlands: Sense Publishers. 2014, p. 181-198.

STETSENKO, A. The Transformative Mind: Expanding Vygotsky's Perspective on Development and Education. New York, NY: Cambridge University Press. 2016.

STETSENKO, A. Putting the radical notion of equality in the service of disrupting inequality in education: Research findings and conceptual advances on the infinity of human potential. Review of Research in Education, [S.1.], v. 41, n. 1, p. 112-135, 2017.

STETSENKO, A. Radical-Transformative Agency: Continuities and Contrasts with Relational Agency and Implications for Education. Frontiers in Education, [S.1.], v. 4, p. 148, 2019. 
173 Polyphonía, v. 32/2, jul./dez. 2021

STETSENKO, A.; ARIEVITCH, I. M. The self in cultural-historical activity theory: Reclaiming the unity of social and individual dimensions of human development. Theory \& Psychology, [S.1.], v. 14, n. 4, p. 475-503, 2004.

VIANNA, E., STETSENKO, A. Turning resistance into passion for knowledge with the tools of agency: teaching-learning about theories of evolution for social justice among foster youth. Perspectiva, Florianópolis, v.37, n. 4, p. 864-886, 2019.

VYGOTSKY, L. S. Mind in society. Cambridge, MA: MIT Press, 1978.

VYGOTSKY, L. S. (1993). The fundamentals of defectology. In RIEBER, W. R.; CARTON, A. S. (ed.). The collected works of L. S. Vygotsky. New York: Plenum Press, 1993. v. 2.

VYGOTSKY, L., RIEBER, R., ROBINSON, D. The Essential Vygotsky: The Collected Works of LS Vygotsky. New York: Plenum, 2004.

WAITOLLER, F. R.; THORIUS, K. K. Cross-Pollinating Culturally Sustaining Pedagogy and Universal Design for Learning: Toward an inclusive pedagogy that accounts for Dis/Ability. Harvard Educational Review, Cambridge, v. 86, n. 3, p. 366-389, 2016.

WILLIAMS, L. B. Student life on the Autism Spectrum: Helping to build a more inclusive campus. Change: The Magazine of Higher Learning, [S.1.], v.48, n.4, p. 48-54. 2016. 